\section{Mononuclear U(IV) complexes and ningyoite as major uranium species in lake sediments}

G. Morin ${ }^{1 *}$, A. Mangeret ${ }^{2}$, G. Othmane ${ }^{1}$, L. Stetten ${ }^{1,2}$,

M. Seder-Colomina ${ }^{1,2}$, J. Brest ${ }^{1}$, G. Ona-Nguema ${ }^{1}$,

S. Bassot ${ }^{2}$, C. Courbet ${ }^{2}$, J. Guillevic ${ }^{2}$, A. Thouvenot ${ }^{3}$,

O. Mathon ${ }^{4}$, O. Proux ${ }^{5}$, J.R. Bargar

\section{Abstract}

doi: 10.7185/geochemlet. 1610

Natural attenuation of uranium in subsurface environments is usually assigned to immobilisation processes due to microbially mediated reduction of $\mathrm{U}(\mathrm{VI})$. Recent laboratory studies have established that the end products of such a process include both low solubility biogenic uraninite and more labile non-crystalline U(IV) species. Indeed, biogenic uraninite formation may be in ibited in the presence of organic or in. to the for inite to the for be phate solids. Such species have been observed in shallow contaminated alluvial aquifers and can thus be suspected to form in other important environments, among which lacustrine sediments have a global environmental significance since they may represent major uranium accumulation reservoirs in riverine watersheds. Here, on the basis of microscopic, spectroscopic and chemical extraction analyses, we report the occurrence of mononuclear U(IV)-phosphate/silicate complexes, accompanied by nano-crystalline ningyoite-like U(IV)phosphate minerals, as major scavengers for uranium in lacustrine sediments downstream from a former uranium mine in France. This observation reveals that uranium trapping mechanisms during early diagenesis of lacustrine sediments can virtually exclude uraninite formation, which has important implications for better modelling uranium cycling in natural

Institut de Minéralogie, de Physique des Matériaux et de Cosmochimie (IMPMC), UMR 7590 CNRSUPMC-IRD-MNHN, case 115, 4 place Jussieu, 75252 Paris Cedex 5, France

Corresponding author (email: guillaume.morin@impmc.upmc.fr)

2. Institut de Radioprotection et de Sûreté Nucléaire, IRSN, PRP-DGE, 31 avenue de la Division Leclerc, 92262 Fontenay-aux-Roses, France

Université de Clermont Ferrand, Athos Environment, 63171 Aubière, France

4. European Synchrotron Radiation Facility (ESRF), BP 220, 38043 Grenoble Cedex, France

5. Observatoire des Sciences de l'Univers de Grenoble (OSUG), UMR CNRS 832, Université GrenobleAlpes, 38041 Grenoble Cedex 9, France - BM30B/CRG-FAME, ESRF, Polygone scientifique Louis Néel, 71 avenue des Martyrs, 38000 Grenoble, France

6. Stanford Synchrotron Radiation Lightsource (SSRL), SLAC National Accelerator National Laboratory, MS 69, 2575 Sand Hill Road, Menlo Park, CA 94025, USA and contaminated freshwaters. Moreover, our results raise issues concerning the long term and contaminated freshwaters. Moreover, our results raise issues concerning the long term respect to re-oxidation events.

Received 4 November 2015 | Accepted 25 January 2016 | Published 16 February 2016

\section{Introduction}

Redox cycling of uranium exerts a major control on its mobility in the environment because of the low solubility of U(IV) phases compared to that of U(VI) ones (Bargar et al., 2008). In natural anoxic environments such as estuarine and coastal sediments, early diagenesis conditions favour the reduction of $\mathrm{U}(\mathrm{VI})$ species into low solubility U(IV) species, which decreases uranium concentrations in overlying waters and sediment pore-waters (Barnes and Cochran, 1993). Researchers addressing remediation of U-contaminated groundwaters have focused on in situ biostimulation strategies involving microbial reduction of U(VI) (Wu et al., 2007 Yabusaki et al., 2007) into biogenic uraninite (Suzuki et al., 2005; Bargar et al, 2008) as well as non-uraninite U(IV) phases (Kelly et al., 2008; Bargar et al., 2013, Alessi et al., 2014a; Newsome et al., 2014). Ex situ incubations of aquifer sediments under anoxic conditions have highlighted the importance of non-crystalline $\mathrm{U}(\mathrm{IV})$ species as major products of microbial reduction of U(VI) (Sharp et al. 2011; Alessi et al., 2014b). In laboratory bioassays, mononuclear U(IV)-phosphate complexes, in which a U(IV) ion coordinates to a $\mathrm{PO}_{4}$ group, have been especially observed as products of microbial U(VI) reduction (Bernier-Latmani et al., 2010; Fletcher et al., 2010; Sivaswamy et al., 2011). U(IV)-phosphate mineral phases as ningyoite $\mathrm{CaU}\left(\mathrm{PO}_{4}\right)_{2} \bullet 2 \mathrm{H}_{2} \mathrm{O}$ have also been identified after microbial reduction of dissolved U(VI) in the presence of phosphate (Bernier-Latmani et al., 2010; Lee et al., 2010) or after reduction of U(VI) phosphate mineral phases (Khijniak et al., 2005; Rui et al., 2013). The occurrence and distribution of non-uraninite U(IV) phases in natural systems is however scarcely documented (Qafoku et al., 2009) Recently, Campbell et al. (2012) showed that non-crystalline mononuclear U(IV) is present in aquifer sediments at the Rifle site. On the basis of this observation, it can be suspected that non-crystalline U(IV) species may form in other reducing environments, among which lacustrine sediments have a global environmenta significance since they represent major uranium accumulation reservoirs in freshwater watersheds. Studies of uranium distribution in lacustrine environments suggested associations of $U$ with organic matter in bottom lake sediments (Ueda et al., 2000; Chappaz et al., 2010) as well as in the water column (Alberic et al., 2000) but no direct determinations of uranium speciation in such environments have been yet reported.

Here we used a combination of X-ray absorption spectroscopy, electron microscopy and selective chemical extraction to investigate uranium speciation in contaminated lake sediments. We show that uranium occurs mainly in the form of mononuclear U(IV)-phosphate/silicate complexes, and to a lesser extent 
as nano-crystalline U(IV)-phosphate of the ningyoite-rhabdophane group. This result has major implications for better predicting the behaviour and fate of uranium in lacustrine environments.

\section{Sampling Site and Analytical Methods}

Sediment cores were sampled in March 2011 and October 2012, with an Uwitec ${ }^{\circledR}$ gravity corer, in the lake Saint-Clément, in a high U geological background area located 20 kilometers downstream from the former uranium mine of Bois Noirs/ Limouzat in the Massif Central, France (Fig. S-1). Core sections were immediately placed in a glove bag, purged with $\mathrm{N}_{2}$, sealed in hermetic containers, transported below $4{ }^{\circ} \mathrm{C}$, and dried under vacuum in a glove-box at the IMPMC laboratory 24 hours after sampling. Samples were preserved under anoxic conditions until and during mineralogical and spectroscopic analyses, and during chemical extractions. For SEM-EDXS analyses, sediments were embedded in epoxy resin and prepared as thin sections. Here, we studied the most concentrated samples collected at 120-123 cm and 143-146 cm depth in the 2012 core and at 190-194 cm depth in the 2011 core, with total bulk U contents of 200,275 and $360 \mathrm{mg} / \mathrm{kg}$ (Fig. S-1; Table S-1). To determine uranium solid-state speciation, we used X-ray Absorption Near Edge Structure (XANES) spectroscopy, Extended X-ray Absorption Fine Structure (EXAFS) spectroscopy at the $\mathrm{U}_{\mathrm{III}}$-edge, and Scanning Electron Microscopy coupled with Energy Dispersive X-ray Spectroscopy (SEM-EDXS) analyses. In addition, we used $1 \mathrm{M} \mathrm{NaHCO}_{3} \mathrm{O}_{2}$-free solution extraction (Alessi et al., 2012) for evaluating the proportion of non-crystalline $\mathrm{U}(\mathrm{IV})$ species in the same samples. See Supplementary Information for detailed procedures.

\section{Identification of U-bearing Minerals in the Sediment Samples}

X-ray diffraction indicated that the sediments consisted mainly of quartz, feldspar, micas and chlorite, in agreement with their chemical composition (Table S-1) and with the granitic geological substratum (Fig. S-1). The high organic carbon content $\sim 12$ wt \% was related to fresh organic matter including vegetal debris. Barite $\left[\mathrm{BaSO}_{4}\right]$ was detected under SEM-EDXS analyses, and pyrite $\left[\mathrm{FeS}_{2}\right]$ was present as rare submicron sized crystals. Systematic SEM observations and EDXS analyses of the 143-146 cm sample revealed scarce U-bearing minerals (Table S-2): zircon, thorite (Fig. S-2), monazite (Fig. S-3), rhabdophane (Figs. S-4, S-5), and a nano-crystalline U-rich phosphate mineral of the ningyoite group (Figs. 1 S-6). Ningyoite was the most concentrated U phase identified in the sample, with the following approximate structural formula: $\left[\left(\mathrm{U}_{0.95} \mathrm{Ca}_{0.3} \mathrm{Fe}_{0.15} \mathrm{Al}_{0.15} \mathrm{Y}_{0.4} \mathrm{Nd}_{0.05}\right)\right.$ $\left.\left(\mathrm{PO}_{4}\right)\left(\mathrm{SiO}_{4}\right) \bullet n \mathrm{H}_{2} \mathrm{O}\right]$ (Table S-2, Fig. S-6). According to Muto et al. (1959), powder XRD data of ningyoite $\left[\mathrm{CaU}\left(\mathrm{PO}_{4}\right)_{2} \cdot 2 \mathrm{H}_{2} \mathrm{O}\right]$ indicate that this mineral is isostructural to rhabdophane $\left[\operatorname{REE}^{3+} \mathrm{PO}_{4} \bullet \mathrm{H}_{2} \mathrm{O}\right]$, with an equivalent amount of $\mathrm{U}^{4+}$ and
$\mathrm{Ca}^{2+}$ ions substituting for the $\mathrm{REE}^{3+}$ ions. In the mineral phase identified here, the excess of $\mathrm{U}^{4+}$ over $\mathrm{Ca}^{2+}$ is likely compensated by $\mathrm{SiO}_{4}{ }^{4-}$ for $\mathrm{PO}_{4}{ }^{3-}$ substitution as in Si-rich ningyoite (Doinikova et al., 2014). Most ningyoite ore deposits are suspected to have formed in reducing zones close to the anoxic-oxic boundary, possibly via microbial activity (Doinikova, 2007) as suggested by laboratory experiments (Khijniak et al., 2005; Bernier-Latmani et al., 2010; Lee et al., 2010, Rui et al., 2013). In the sediments studied here, evaluating the importance of the U(IV) mineral phases with respect to other uranium species required both bulk XANES and EXAFS analyses and selective chemical extractions assays.
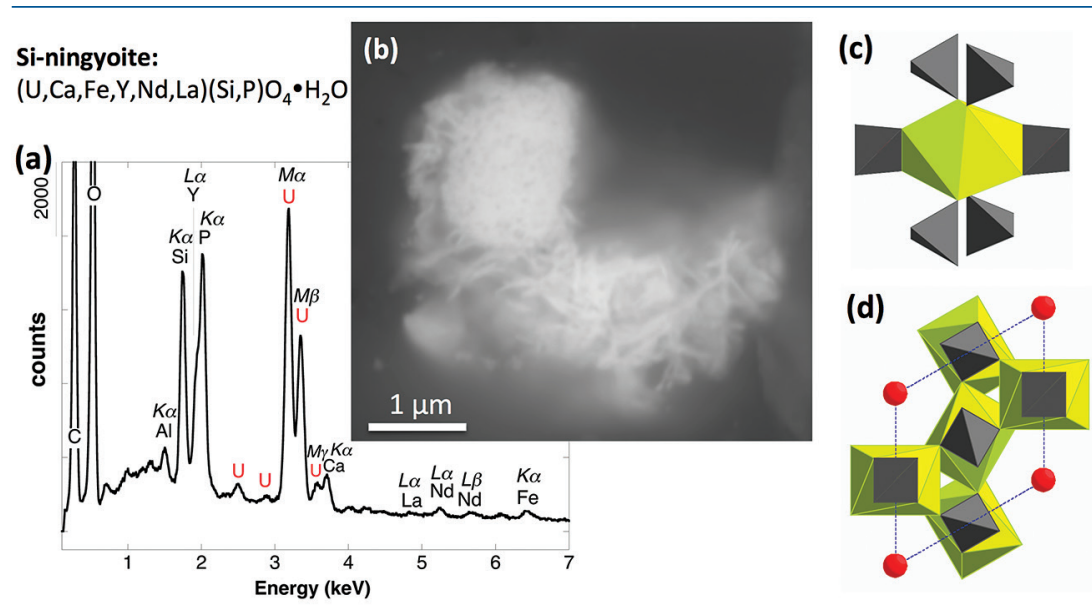

Figure 1 (a) EDXS analysis (Table S-2) and (b) Backscattered electron SEM image of Siningyoite in sample $143-146 \mathrm{~cm}$ with nano-sized acicular shaped crystals characteristic of the ningyoite in sample $143-146 \mathrm{~cm}$ with nano-sized acicular shaped crystals characteristic of the low) to phosphate tetrahedra (gray), and (d) cation polyhedra in the ningyoite/rhabdophane structure (Table S-4).

\section{Uranium Oxidation State}

XANES analyses at the $\mathrm{U}_{\amalg \amalg}$-edge indicated that uranium was mainly present as U(IV) in the sediment samples studied (Fig. 2a). Indeed, the shoulder at $\sim 17190 \mathrm{eV}$ that is characteristic of the uranyl ion, e.g., in U(VI)-pyrophosphate (Figs. 3a, S-7), was not observed in the XANES spectra of the sediment samples (Figs. 2a, 7a). Linear Combination Fitting (LCF) of the XANES spectra indicated that the proportion of U(VI) accounted at most for $20 \%$ of total U in the $143-146 \mathrm{~cm}$ sample and was below $10 \%$ of total $U$ in the two other sediment samples (Fig. 2a, Table S-3). 


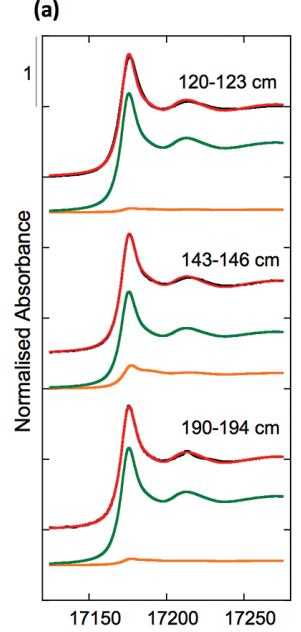

Energy (eV)

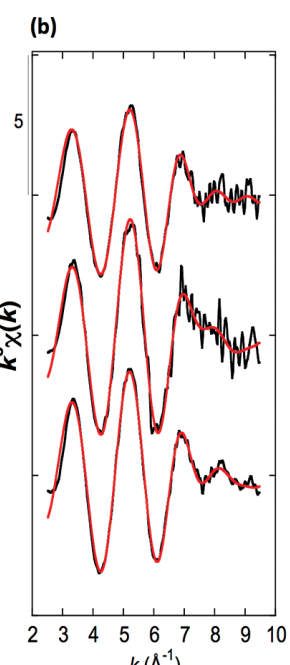

$k\left(\AA^{-1}\right)$

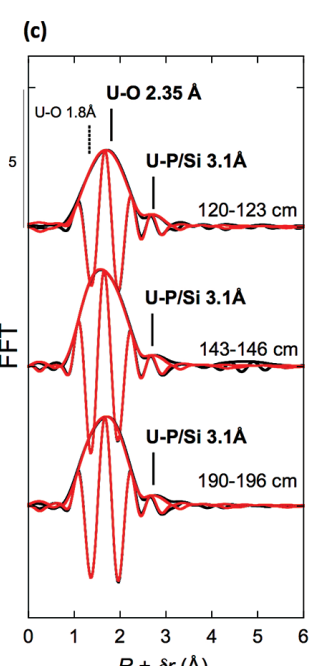

$R+\operatorname{sr}(\AA)$

Figure 2 Uranium L LII-edge XANES and EXAFS data of the lake sediment samples (black). (a) Linear Combination Fits (red) of the XANES spectra included U(IV) citrate (green) and U(VI) pyrophosphate (orange) as components. (b) Shell-by-shell fits (red) of the unfiltered $k^{3} \gamma(k)$ EXAFS spectra and (c) their Fast Fourier Transforms. See Table $S-3$ for fitting parameters.

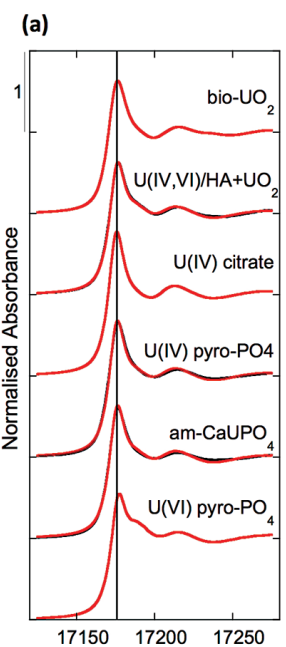

Energy (eV)

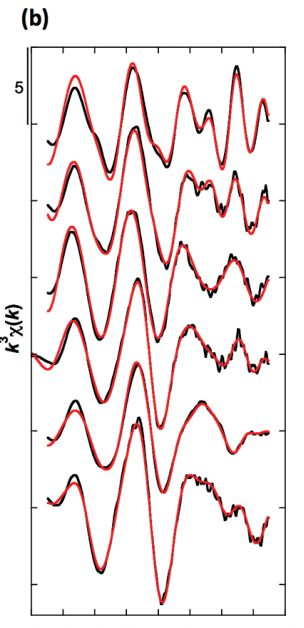

$\begin{array}{lllllllllll}2 & 3 & 4 & 5 & 6 & 7 & 8 & 9 & 10\end{array}$ $k\left(\AA^{-1}\right)$

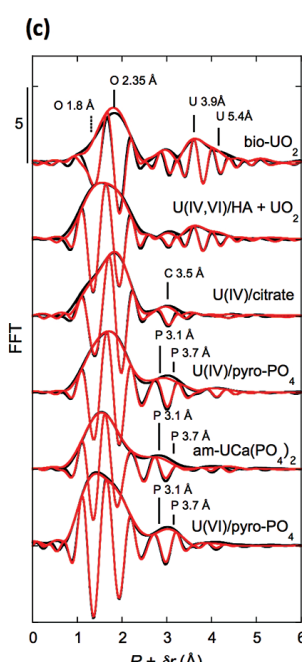

$R+\delta r(A)$

Figure 3 Uranium LII-edge XANES and EXAFS data of relevant model compounds (black). (a) Linear Combination Fits (red) of the XANES spectra, (b) shell-by-shell fits (red) of the unfiltered $k^{3} \chi(k)$ functions and (c) their Fast Fourier Transforms. See Table S-3 for fitting parameters.

\section{Chemical Extraction as a Probe for Mononuclear U(IV) Species}

The proportion of mononuclear U(IV) species in the sediment samples was evaluated by selective chemical extraction using a $1 \mathrm{M} \mathrm{NaHCO}_{3} \mathrm{O}_{2}$-free solution under anoxic conditions using the protocol of Alessi et al. (2012) (Supplementary Information). As shown in Figure $4 a, 65 \pm 5 \%$ of the total uranium content was extracted from the three samples by this method, and could be assigned to mononuclear U(IV). Indeed, non-crystalline U(IV) species may include mononuclear and polymerised U(IV)-complexes, the latter being less extractable than the former (Alessi et al , 2014b). U(IV)-bearing minerals identified by SEM-EDXS, including ningyoite, rhabdophane, thorite and zircon, thus likely accounted at most for $35 \pm 5 \%$ of the total uranium in the sediment samples.
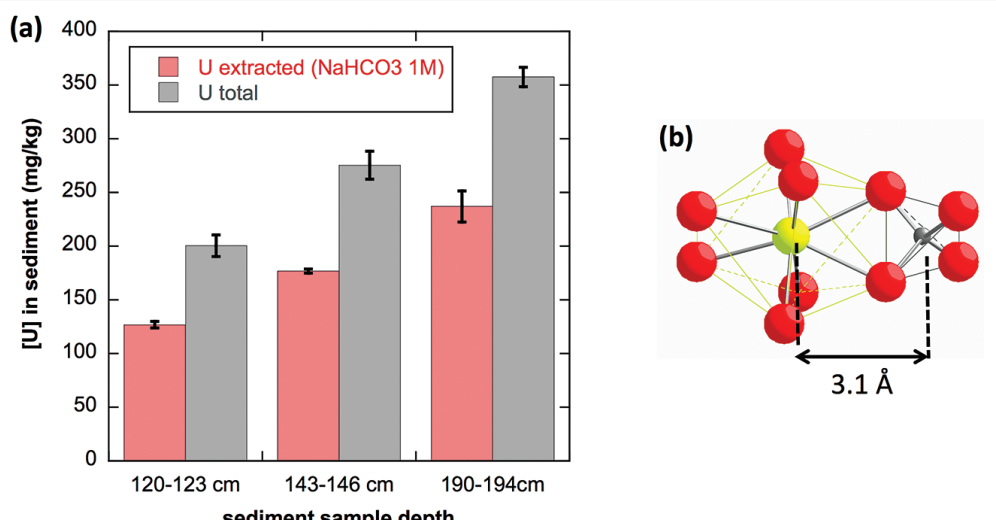

Figure 4 (a) Concentration of U(IV) extracted by $\mathrm{O}_{2}$-free $\mathrm{NaHCO}_{3}(1 \mathrm{M})$ solution compared to total bulk U. (b) Local structure of mononuclear U(IV)-phosphate/silicate bidendate edgeto total bulk $\mathrm{U}$. (b) Local structure of monon sediments studied (Fig. 2. Table S-3). The phosphate/silicate tetrahedron could be connected to either organic or inorganic substrates.

\section{EXAFS Evidence for Mononuclear U(IV)-phosphate/silicate} Complexes as Major U Species

U L ${ }_{\amalg-}$-edge EXAFS data of the three sediment samples were rather similar to each other (Fig. 2b,c), and significantly different from that of biogenic nanouraninite (Fig. 3b,c). Indeed, best fits of the sediment sample data were obtained with 8-9 U-O scattering paths at $\sim 2.35 \AA$ and $\sim 1$ U-P or U-Si path at $\sim 3.1 \AA$, with similar fit quality for a P or Si neighbour (Figs. 2c, S-8, Table S-3). The U-O paths were consistent with $\mathrm{U}^{4+}$ ions 8 -fold coordinated to oxygen atoms (Table S-4). A minor U-O path at a distance of $\sim 1.8 \AA$ improved the fits, accounting for $<5-20 \%$ of uranyl ions identified by XANES analysis (Fig. 2a, Table S-3). 
The observed U-P/Si distance of $\sim 3.1 \AA$ corresponds to edge-sharing bidentate bridging of the $\mathrm{UO}_{8}$ group to a $\mathrm{PO}_{4} / \mathrm{SiO}_{4}$ tetrahedron (Rui et al., 2013) (Fig. $4 \mathrm{~b}$, Table S-4), such U-P distance being characteristic of non-uraninite U(IV) species identified as products of microbial (Bernier-Latmani et al., 2010; Lee et al., 2010; Boyanov et al., 2011) or abiotic (Veeramani et al., 2011) U(VI) reduction. Moreover, a sole $\mathrm{P} / \mathrm{Si}$ atom was detected beyond the first oxygen coordination sphere of the $U$ absorber, which contrasts with the higher number of second neighbours observed for amorphous U(IV) phases (Table S-3, Fig. S-9). This result demonstrated that uranium was mainly present as mononuclear U(IV)-phosphate/silicate complexes in the sediment, likely accounting for most of the extractable U(IV) fraction ( $65 \pm 5 \%$ of total U in Fig. 4).

Neither the U-U paths of the uraninite structure (Fig. 3), nor the U-P/Si at 3.7-3.8 $\AA$ (Fig. 1c) and U-U/Th/Ca/REE paths at 3.6-4.1 $\AA$ (Fig. 1d) that are characteristic of crystalline (Table S-4) and amorphous (Fig. S-9) U(IV)-bearing phosphate and silicate mineral phases, were detected around the U absorber in the sediments (Fig. 2c, Table S-3). Owing to the sensitivity of EXAFS to minor components (Alessi et al., 2012), crystalline phases thus accounted for less than $10 \%$ of $U$, suggesting that the non-extractable $U$ fraction in the sediment (35 $\pm 5 \%$ of total U in Fig. 4) consisted of nano-crystalline or amorphous U(IV) phases. For instance, biogenic nano-crystalline U(IV) is not easily extracted by $1 \mathrm{M} \mathrm{NaHCO}_{3}$ (Alessi et al., 2014b). We thus infer that a fraction of the primary $\mathrm{U}(\mathrm{IV})$-bearing uranium minerals identified by SEM-EDXS, as zircon and thorite are likely metamict because of their high $\mathrm{U}$ and Th contents (Table S-2), which would make such phases difficult to detect by EXAFS as minor phases in a mixture with mononuclear U(IV) complexes. Accordingly, $\sim 1$ instead of $4 \mathrm{Pu}-\mathrm{Zr}$ paths at $3.6 \AA$ were reported for Pu LII-edge EXAFS analysis of highly metamict zircon (Begg et al., 2000). In the same way, 2 to 4 times less $P$ and U neighbours were observed by EXAFS in our amorphous U(IV) model compounds (Table S-3, Fig. 3) than in their crystalline analogues (Table S-4).

Finally, Continuous Cauchy Wavelet Transform analysis of the EXAFS data confirmed that mononuclear U(IV) was mainly complexed to phosphate or silicate groups, even if a minor contribution from carboxylic/phenolic or carbonate groups could not be excluded (Fig. S-8). Hence, our EXAFS results indicated that uranium was mainly in the form of mononuclear U(IV)-phosphate/silicate complexes in the sediments studied and thus provide a direct clue of the importance of such species in lacustrine systems.

\section{Environmental Implications}

The knowledge of uranium speciation in natural sediments impacted by anthropogenic activities is essential for predicting the fate of uranium during and after sediment deposition. In that context, lacustrine sediments are of particular importance because they represent important accumulation reservoirs for this element in continental watersheds. The present study yields evidence for mononuclear U(IV)-phosphate complexes as the main uranium species in lake sediments impacted by a former uranium mine. This observation reveals that uranium trapping mechanisms during early diagenesis of lacustrine sediments can virtually exclude uraninite formation, which has important implications for modelling uranium cycling in natural and contaminated freshwater systems. The absence of uraninite in the sediments studied here supports previous laboratory studies attesting that phosphate ions can inhibit uraninite precipitation (Khijniak et al., 2005; Bernier-Latmani et al., 2010; Lee et al., 2010; Boyanov et al., 2011; Rui et al., 2013), and suggest that silicate could act similarly in natural systems. Our results also indicate that $\mathrm{U}(\mathrm{IV})$-phosphates such as ningyoite, although present, account for a minor fraction of the total U(IV). Such a phase could have formed in the sediment after bioreduction of either soluble U(VI) (Bernier-Latmani et al. 2010) or, more likely, of a secondary U(VI)-phosphate/silicate mineral inherited from the uranium ore (Rui et al., 2013) (Fig. S-1).

Importantly, we show the predominance of mononuclear U(IV)-phosphate/ silicate species, in agreement with results of laboratory studies involving U(VI) reduction in the presence of phosphate (Bernier-Latmani et al., 2010; Fletcher et al., 2010; Sivaswamy et al., 2011; Boyanov et al., 2011; Veeramani et al., 2011; Sharp et al., 2011; Alessi et al., 2014b). Such U(IV) mononuclear species could either be sorbed to the surface of phosphate (Veeramani et al., 2011) as well as silicate minerals, or be bound to organic phosphoryl groups (Alessi et al., 2014b). The major occurrence of such species in lacustrine sediments has important environmental implications since mononuclear U(IV) species are potentially more labile than uraninite (Cerrato et al., 2013; Alessi et al., 2014a) and polymerised non-crystalline U(IV) phosphate phases (Alessi et al., 2014b). Such lability raises issues concerning the long term fate of the mononuclear U(IV) species, especially when subjected to sharp redox changes, for example in sediment remediation strategies as dredging operations.

\section{Acknowledgements}

We thank Dr. Evelyne Barker, Dr. Imène Esteve and Sebastien Charron, and Loic Martin and Ludovic Delbès, for their help in chemical, SEM, and XRD analyses, respectively. We also thank Prof. Jordi Bruno and another anonymous reviewer for their constructive comments that have helped us to improve the quality of the manuscript. This study was supported by IRSN and CNRS-NEEDS Program. We thank EDF and DREAL Auvergne for having authorised access to the lake of Saint-Clément. The SEM equipment of IMPMC was funded by Région IDF, CNRS, UPMC and ANR. ESRF, French CRG and SSRL facilities are acknowledged for having provided beamtime. SSRL and SLAC are supported by the U.S. Department of Energy (DOE), Office of Science, Office of Basic Energy Sciences under Contract No. DE-AC02-76SF00515, the DOE Office of Biological 
and Environmental Research (BER), and by the National Institutes of Health, National Institute of General Medical Sciences (including P41GM103393). Partial support was provided by the U.S. DOE BER and SBR program.

Editor: Rodney C. Ewing

\section{Additional Information}

Supplementary Information accompanies this letter at www.geochemicalperspectivesletters.org/article1610

Reprints and permission information is available online at http://www. geochemicalperspectivesletters.org/copyright-and-permissions

Cite this letter as: Morin, G., Mangeret, A., Othmane, G., Stetten, L., SederColomina, M., Brest, J., Ona-Nguema, G., Bassot, S., Courbet, C., Guillevic, J. Thouvenot, A., Mathon, O., Proux, O., Bargar, J.R. (2016) Mononuclear U(IV) complexes and ningyoite as major uranium species in lake sediments. Geochem. Persp. Let. 2, 95-105.

\section{References}

Alberic, P., Viollier, E., JeZequel, D., Grosbois, C., Michard, G. (2000) Interactions between trace elements and dissolved organic matter in the stagnant anoxic deep layer of a meromictic lake. Limnology and Oceanography 45, 1088-1096.

Alessi, D.S., Uster, B., Veeramani, H., Suvorova, E.I., Lezama-Pacheco, J.S., Stubbs, J.E. BARGAR, J.R., BERNIER-LATMANI, R. (2012) Quantitative Separation of Monomeric U(IV) from $\mathrm{UO}_{2}$ in Products of $\mathrm{U}(\mathrm{VI})$ Reduction. Environmental Science and Technology 46, 6150-6157.

Alessi, D.S., Lezama-Pacheco, J.S., Janot, N., Suvorova, E.I., Cerrato, J.M., Giammar, D.E., Davis, J.E., Fox, P.M., Williams, K.H., LonG, P.E., HandleY, K.M., BernierLATMANI, R., BARGAR, J.R. (2014a) Speciation and Reactivity of Uranium Products Formed during in Situ Bioremediation in a Shallow Alluvial Aquifer. Environmental Science and Technology $48,12842-12850$

Alessi, D.S., Lezama-Pacheco, J.S., Stubbs, J.E., Janousch, M., Bargar, J.R., Persson, P., BERNIER-LATMANI, R. (2014b) The product of microbial uranium reduction includes multiple species with U(IV)-phosphate coordination. Geochimica et Cosmochimica Acta 131, 115-127.

Bargar, J.R., Bernier-Latmani, R., Giammar, D.E., Tebo, B.M. (2008) Biogenic uraninite nanoparticles and their importance for uranium remediation. Elements 4, 407-412.

Bargar, J.R., Williams, K.H., Campbell, K.M., Long, P.E., Stubbs, J.E., Suvorova, E.I., LeZama-Pacheco, J.S., Alessi, D.S., Stylo, M., Webb, S.M., Davis, J.A., Giammar, D.E., BLUE, L.Y., BERNIER-LATMANI, R. (2013) Uranium redox transition pathways in acetateamended sediments. Proceedings of the National Academy of Science of the USA 110, 4506-4511.

BARNES, C.E., COCHRAN, J.K. (1993) Uranium geochemistry in estuarine sediments: controls on removal and release processes. Geochimica et Cosmochimica Acta 57, 555-589.
BegG, B.D., Hess, N.J., Weber, W.J., ConRadson, S.D., Schweiger, M.J., Ewing, R.C. (2000) XAS and XRD study of annealed ${ }^{238} \mathrm{Pu}$ - and ${ }^{239} \mathrm{Pu}$-substituted zircons $\left(\mathrm{Zr}_{0.92} \mathrm{Pu}_{0.08} \mathrm{SiO} 4\right)$. Journal of Nuclear Materials 278, 212-224.

Bernier-Latmani, R., Veeramani, H., Dalla Vecchia, E., Junier, P., Lezama-Pacheco, J.S., Suvorova, E.I., Sharp, J.O., Wigginton, N.S., BARGaR, J.R. (2010) Non-uraninite products of microbial U(VI) reduction. Environmental Science and Technology 44, 9456-9462.

Boyanov, M.I., Fletcher, K.E., Kwon, M.J., Rui, X., O’Loughlin, E.J., Löffler, F.E., Kemner, K.M. (2011) Solution and microbial controls on the formation of reduced U(IV) phases. Environmental Science and Technology 45, 8336-8344.

Campbell, K.M., KukKadapu, R.K., Qafoku, N.P., Peacock, A.D., Lesher, E., Williams, K.H., Bargar, J.R., Wilkins, M.J., FigueroA, L., Ranville, J., Davis, J.A., Long, P.E. (2012) Geochemical, mineralogical and microbiological characteristics of sediment from a naturally reduced zone in a uranium-contaminated aquifer. Applied Geochemistry 27, 1499-1511.

Cerrato, J.M., Asner, M.N., Alessi, D.S., Lezama-Pacheco, J.S., Bernier-Latmani, R. BARGAR, J.R., GIAMMAR, D.E. (2013) Relative reactivity of biogenic and chemogenic uraninite and biogenic non crystalline U(IV). Environmental Science and Technology 47, 9756-9763.

Chappaz, A., Gobeil, C., Tessier, A. (2010) Controls on uranium distribution in lake sediments. Geochimica et Cosmochimica Acta 74, 203-214.

DoINIKOVA, O.A. (2007) Uranium Deposits with a new phosphates types of blacks. Geology of Ore Deposits 49, 80-86.

DOINIKOVA, O.A., SidORENKO, G.A., SivtSOV, A.V. (2014) Phosphosilicates of tetravalent uranium. Doklady Earth Sciences 456, 755-758.

Fletcher, K.E., Boyanov, M.I., Thomas, S.H., Wu, Q., Kemner, K.M., LÖffler, F.E. (2010) U(VI) reduction to mononuclear U(IV) by Desulfitobacterium species. Environmental Science and Technology 44, 4705-4709.

Kelly, S.D, Kemner, K.M., Carley, J., Criddle, C., Jardine, P.M., Marsh, T.L., Phillips, D, WATSON, D., WU, W.M. (2008) Speciation of uranium in sediments before and after in situ biostimulation. Environmental Science and Technology 42, 1558-1564.

Khijniak, T.V., Slobodkin, A.I., COKer, V., Renshaw, J.C., Livens, F.R., BOnCh-OSmoLOVSKAYA, E.A., BiRKELAND, N.K., MEDVEDEVA-LYALIKOVA, N.N., LLOYD, J.R. (2005) Reduction of Uranium(VI) Phosphate during Growth of the Thermophilic Bacterium Thermoterrabacterium ferrireducens. Applied and Environmental Microbiology 71, 6423-6426.

LEE, S.Y., BAIK M.H., CHOI, J.W. (2010) Biogenic formation and growth of uraninite $\left(\mathrm{UO}_{2}\right)$. Environmental Science and Technology 44, 8409-8414.

Muto, T., Meyrowitz, R., POMmer, A., Murano, T. (1959) Ningyoite, a new uranous phosphate mineral from Japan. American Mineralogist 44, 633-650.

Newsome, L., MorRIS, K., LLOYD, J.R. (2014) The biogeochemistry and bioremediation of uranium and other priority radionuclides. Chemical Geology 363, 164-184.

QAfoku, N.P., Nikolla, P., KukKadapu, R.K., Ravi, K., Mckinley, J.P., James, P., Arey, B.W., KeLLY, S.D., WANG, C.M., RESCH, C.T, LONG, PE. (2009) Uranium in framboida pyrite from a naturally bioreduced alluvial sediment. Environmental Science and Technology 43, 8528-8534.

Rui, X. Kwon, M.J., O’Loughlin, E.J., Dunham-Cheatham, S., Fein, J.B., Bunker, B Kemner, K. M., Boyanov, M.I. (2013) Bioreduction of Hydrogen Uranyl Phosphate: Mech nisms and U(IV) Products. Environmental Science and Technology 47, 5668-5678.

Sharp, J.O., Lezama-Pcheco, J.S., Schofield, E.J., Junier, P., Ulrich, K-U., Chinni, S Veeramani, H., Margot-Roquier, C., Webb, S.M., Tebo, B.M., Giammar, D.E. BARGAR, J.R., BERNIER-LATMANI, R. (2011) et Uranium speciation and stability after reductive immobilization in aquifer sediments. Geochimica et Cosmochimica Acta 75, 6497-6510. 
Sivaswamy, V., Boyanov, M.I., Peyton, B.M., Viamajala, S., Gerlach, R., Apel, W.A., San R.K., DOHnalKova, A., Kemner, K.M., BOrCh, T. (2011) Multiple Mechanisms of Uranium Immobilization by Cellulomonas sp. Strain ES6. Biotechnology and Bioengineering 108, 264-276.

SuZUKI, Y., KelLy, S.D., KEMNER, K.A., BANFIELD, J.F. (2005) Microbial populations stimulated for hexavalent uranium reduction in uranium mine sediment. Applied Environmental Microbiology 69, 1337-1346.

Ueda, S., Hasegawa, H., Iyogi, T., Kawabata, H., Kondo, K. (2000) Investigation of physicochemical form of uranium in sediment of brackish Lake Obushi using sequential extraction procedure. Limnology 13, 231-236.

Veeramani, H., Alessi, D., Suvorova, E., Lezama-Pacheco, J., Stubbs, J., Dippon, U., KAPPLER, A., BARGAR, J., BERNIER-LATMANI, R. (2011) Products of abiotic U(VI) reduction by biogenic magnetite and vivianite. Geochimica et Cosmochimica Acta 75, 2512-2528.

Wu, W.M., Carley, J., Luo, J., Ginder-Vogel, M.A., Cardenas, E., Leigh, M.B., Hwang, C.C., Kelly, S.D., Ruan, C.M., Wu, L.Y., Van Nostrand, J., Gentry, T., Lowe, K., C.C., KELLY, S.D., RUAN, C.M., WU, L.Y., VAN NOSTRAND, J., GENT, T., LOWE, K, K.M. K.M., MARSH, T., TLEDE, J., ZHOU, J.Z., FENDORF, S., KITANDIS, P.K., JARDINE, P.M., CRIDDLE, C.S. (2007) In situ bioreduction of uranium(VI) to submicromolar levels and reoxidation by dissolved oxygen. Environmental Science and Technology 41, 5716-5723.

Yabusaki, S.B., Fang, Y., Long, P.E., Resch, C.T., Peacock, A.D., Komlos, J., Jaffe, P.R., MorRIson, S.J., DAYvaUlt, R.D., White, D.C., ANDERSON, R.T. (2007) Uranium removal from groundwater via in situ biostimulation: field-scale modeling of transport and biological processes. Journal of Contaminant Hydrology 93, 216-235. 